\title{
Gout without crystals on initial synovial fluid analysis
}

\author{
NORMAN R. ROMANOFF \\ M.D.
}

\author{
Alan Rubinow \\ M.D.
}

Mecti

Rheumatology Section, Boston Veterans Administration Hospital and the Arthritis and Connective Tissue Disease Section, Boston University Medical Center

\author{
JuAN J. CANOSO \\ M.D., F.A.C.P. \\ Elizabeth C. Spark \\ M.D.
}

\begin{abstract}
Summary
In five patients with acute arthritis in whom gout was eventually documented, an initial synovial fluid analysis failed to reveal urate crystals. Four of the patients were seen in one hospital during a period of 30 months in which 103 cases of gout were documented on initial aspiration. While this is an uncommon event, the importance of being able to make a definitive diagnosis of gout is such that re-aspiration of the same or other joints may be justified under certain circumstances.
\end{abstract}

\section{Introduction}

A definitive diagnosis of acute gouty arthritis is based upon the identification of urate crystals in the synovial fluid (SF) (McCarty and Hollander, 1961). In some patients, however, an initial SF analysis may not reveal crystals although they may be subsequently found on re-aspiration of the same or different joint (Schumacher et al., 1975). Five patients with this phenomenon are now reported, and an estimate is made of its frequency in a gouty population.

\section{Methods and case reports}

Synovial fluid was aspirated into sterile syringes and transferred to heparinized and non-heparinized tubes after appropriate cultures were obtained. Each specimen was examined for at least $30 \mathrm{~min}$ on a polarizing microscope by a rheumatology fellow and a staff rheumatologist. A mucin clot test, leucocyte count, Gram stain, and a differential count using the Wright-Giemsa stain were performed on each fluid (Cohen, Brandt and Krey, 1975).

\section{Case 1}

A 56-year-old man with a history of gout presented ten days after the onset of pain and swelling of the right ankle. He had taken colchicine before

Correspondence: J. J. Canoso, M.D., Rheumatology Section, Boston Veterans Administration Hospital, 150 South Huntington Avenue, Boston, Massachusetts 02130, U.S.A. admission, but without relief. On examination, his temperature was $37 \cdot 8^{\circ} \mathrm{C}$ and his right ankle region was acutely inflamed. Laboratory investigations showed a haematocrit of $33 \%$, white blood count (WBC) $7 \cdot 7 \times 10^{9} / 1$, blood urea nitrogen $13 \mathrm{mg} / \mathrm{dl}$, and serum urate $6.6 \mathrm{mg} / \mathrm{dl}$ (normal $<8.3 \mathrm{mg} / \mathrm{dl}$ ). The right subtalar joint was aspirated and turbid SF was obtained. The SF was highly inflammatory and no crystals were identified. A Gram stain was negative (Table 1). The right ankle was then aspirated and one drop of fluid was obtained in which no crystals were found. Since gout was still strongly suspected, the patient was begun on colchicine. That evening his temperature rose to $38.4^{\circ} \mathrm{C}$. By this time, the ankle had improved but the left wrist became acutely inflamed. Aspiration of the wrist yielded a trace amount of fluid in which many urate crystals were identified. Colchicine was discontinued and indomethacin was initiated with rapid improvement of all involved joints. Antinuclear antibodies (ANA), latex fixation and multiple cultures including blood, $\mathrm{SF}$, throat, rectum and urethra, were negative.

\section{Case 2}

A 26-year-old man presented with pain and swelling of the left knee of two days' duration. He denied backache as well as ocular, cutaneous, bowel or urethral symptoms. Several of his immediate relatives were obese, and his mother and one sister had diabetes. On examination, his temperature was $38^{\circ} \mathrm{C}$ and his weight was $115 \mathrm{~kg}$. The left knee was held in flexion and was erythematous, warm, diffusively tender and had a tense effusion. Laboratory investigations showed a haematocrit of $46 \%$, WBC $10.8 \times 10^{\circ} / 1$ with $66 \%$ polymorphonuclear cells (PMNs), erythrocyte sedimentation rate (ESR) $5 \mathrm{~mm}$ in the first hour (Westergren), serum urate $9.4 \mathrm{mg} / \mathrm{dl}$ and fasting serum triglycerides $343 \mathrm{mg} / \mathrm{dl}$ (normal $<135 \mathrm{mg} / \mathrm{dl}$ ). Urinalysis was normal. Serum creatinine, glucose, transaminase, alkaline phosphatase, and cholesterol were normal. The knee 
TABLE 1. Synovial fluid (SF) analysis

\begin{tabular}{|c|c|c|c|c|c|c|c|c|}
\hline & $\begin{array}{l}\text { Date of } \\
\text { aspiration }\end{array}$ & Joint & $\begin{array}{l}\text { Volume } \\
\text { (ml) }\end{array}$ & $\mathrm{WBC}^{*} \times 10^{9} / 1$ & $\%$ PMNs $\dagger$ & $\begin{array}{l}\text { SF/blood } \\
\text { glucose } \\
(\mathrm{mg} / \mathrm{dl})\end{array}$ & Crystals & 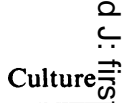 \\
\hline Patient 1 & $\begin{array}{l}\text { 10th Sept. } 1974 \\
\text { 10th Sept. } 1974 \\
\text { 11th Sept. } 1974\end{array}$ & $\begin{array}{l}\text { (R) subtalar } \\
\text { (R) ankle } \\
\text { (L) wrist }\end{array}$ & $\begin{array}{l}1 \\
\text { trace } \\
\text { trace }\end{array}$ & $\begin{array}{c}40 \cdot 8 \\
-\end{array}$ & $\frac{92}{-}$ & 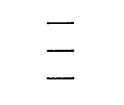 & $\begin{array}{l}\text { none } \\
\text { none } \\
\text { urate }\end{array}$ & $\begin{array}{c}\text { negativ区 } \\
\text { negative } \\
-\frac{\bar{\sigma}}{\bar{T}}\end{array}$ \\
\hline Patient 2 & $\begin{array}{l}\text { 29th July } 1975 \\
\text { 30th July } 1975 \\
\text { 4th Sept. } 1975\end{array}$ & $\begin{array}{l}\text { (L) knee } \\
\text { (L) knee } \\
\text { (L) knee }\end{array}$ & $\begin{array}{l}45 \\
60 \\
60\end{array}$ & $\begin{array}{r}33 \cdot 6 \\
25 \cdot 3 \\
9 \cdot 7\end{array}$ & $\begin{array}{l}83 \\
84 \\
74\end{array}$ & $\begin{array}{l}85 / 90 \\
100 / 110 \\
120\end{array}$ & $\begin{array}{l}\text { none } \\
\text { none } \\
\text { urate }\end{array}$ & $\begin{array}{l}\text { negative } \\
\text { negative } \\
\text { negative }\end{array}$ \\
\hline Patient 3 & $\begin{array}{l}\text { 12th Feb. } 1976 \\
\text { 13th Feb. } 1976\end{array}$ & $\begin{array}{l}\text { (L) elbow } \\
\text { (L) elbow }\end{array}$ & $\begin{array}{l}4 \\
2\end{array}$ & $\begin{array}{l}40 \cdot 3 \\
45 \cdot 0\end{array}$ & $\begin{array}{l}93 \\
95\end{array}$ & - & $\begin{array}{l}\text { none } \\
\text { urate }\end{array}$ & $\begin{array}{l}\text { negative- } \\
\text { negative्ध }\end{array}$ \\
\hline Patient 4 & $\begin{array}{l}\text { 3rd May } 1976 \\
\text { 3rd May } 1976\end{array}$ & $\begin{array}{l}\text { (R) hip } \\
\text { (R) 1st } \\
\text { metatarso- } \\
\text { phalangeal }\end{array}$ & $\begin{array}{c}9 \\
\text { trace }\end{array}$ & $15 \cdot 6$ & $\begin{array}{l}83 \\
-\end{array}$ & $\begin{array}{c}57 / 109 \\
-\end{array}$ & $\begin{array}{l}\text { none } \\
\text { urate }\end{array}$ & negativg \\
\hline Patient 5 & $\begin{array}{r}\text { 9th Aug. } 1976 \\
\text { 15th Nov. } 1976\end{array}$ & $\begin{array}{l}\text { (R) knee } \\
\text { (L) knee }\end{array}$ & $\begin{array}{l}12 \\
40\end{array}$ & $\begin{array}{r}1 \cdot 6 \\
28 \cdot 5\end{array}$ & $\begin{array}{l}37 \\
84\end{array}$ & 99/- & $\begin{array}{l}\text { none } \\
\text { urate }\end{array}$ & $\begin{array}{l}\text { negative } \\
\text { negative }\end{array}$ \\
\hline
\end{tabular}

* WBC, white blood cells; † PMNs, polymorphonuclear cells.

was aspirated on admission and again the following day. The SF was highly inflammatory. No urate crystals were identified and a Gram stain was negative (Table 1). No medications were given. He became afebrile by the third day, the swelling resolved and he was discharged asymptomatic by the tenth day of hospitalization. Tests reported normal or negative included ANA, latex fixation, serum and SF complement, antistreptolysin O, hepatitis B surface antigen and cultures of blood, SF, throat, rectum and urethra. The 24 -hr urine uric acid was $626 \mathrm{mg}$. X-ray studies of sacro-iliac joints and upper and lower gastro-intestinal tract were normal.

Four weeks after discharge, he returned with acute arthritis of both knees and right ankle. Aspiration of the left knee revealed an inflammatory fluid with many intracellular urate crystals (Table 1). Indomethacin therapy was initiated with prompt response. He was discharged on colchicine and the appropriate diet without recurrence of the gout in the ensuing 18 months.

\section{Case 3}

A 60 -year-old man with a history of hypertension was admitted one day after the onset of pain and swelling in his left elbow. On examination, his temperature was $37^{\circ} \mathrm{C}$ and his blood pressure was $140 / 90$ mmHg. A hot, painful, swollen left elbow was held in $45^{\circ}$ flexion. Laboratory investigations showed a haematocrit of $31 \%$, WBC $7.0 \times 10^{9} / 1$ and serum urate $9 \cdot 2 \mathrm{mg} / \mathrm{dl}$. The elbow was aspirated, and turbid, highly inflammatory SF was obtained. No crystals were identified (Table 1). Repeat aspiration $12 \mathrm{hr}$ later again revealed inflammatory fluid but urate crystals were now seen. The patient was treated wi colchicine and discharged $24 \mathrm{hr}$ later, greatly inaproved. Blocd, SF and urethral cultures were nega tive.

\section{Case 4}

A 50-year-old man was admitted with a 24 -19 history of malaise, shaking chills and pain in his righr groin and thigh. On examination, his temperatuoge was $38^{\circ} \mathrm{C}$ and the right hip was held in flexion. Attempts to move his hip elicited severe pain. The 1st metatarso-phalangeal joint (MTP) was tende Laboratory investigations showed a haematocrit of $42 \%$, WBC $7 \cdot 1 \times 10^{\circ} / 1$ with $65 \%$ PMNs and $5 \%$ banf forms, ESR $30 \mathrm{~mm}$ in $1 \mathrm{hr}$ and serum urate 6:9 $\mathrm{mg} / \mathrm{dl}$. X-rays of both hips were normal. The hi⿱ was aspirated under fluoroscopic control and turbid]; inflammatory SF was obtained in which no crystałs were identified. A Gram stain was negative (Table 1 . The tender MTP joint was then aspirated and a dro of bloody fluid was obtained in which urate crystads were found. The patient was treated with colchicine and two days later he was able to walk. Blood and cultures were negative.

\section{Case 5}

A 42-year-old man with a history of recurren episodes of arthritis in knees and feet was evaluateg two days after the onset of pain in his right knee. Hits temperature was $37^{\circ} \mathrm{C}$ and the knee contained am effusion and was tender. Serum urate was $8.8 \mathrm{mg} / \mathrm{d}$. $\mathrm{X}$-ray studies of knees and ankles revealed distensiog of the right supra-patellar pouch. Joint aspiration yielded a mildly inflammatory fluid in which $\overrightarrow{\mathrm{m}}$

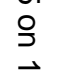


crystals were found (Table 1). The synovitis subsided spontaneously. Three months later the patient returned $24 \mathrm{hr}$ after the onset of pain in his left knee. He described an episode of podagra which had resolved three days before the onset of pain in the left knee. Aspiration of the knee revealed a highly inflammatory fluid in which intra- and extracellular urate crystals were identified (Table 1 ). He was treated successfully with indomethacin. Latex fixation and ANA were negative.

\section{Discussion}

In earlier series (Zvaifler and Pekin, 1963; McCarty, 1965) urate crystals were not found in approximately $5 \%$ of gouty effusions. However, it is not known whether ultimate demonstration of crystals was made in all. Recently there has been a detailed report of nine patients with acute gout in whom crystals were not found on initial SF analysis but on repeat aspiration of the same or other joint (Schumacher et al., 1975). However, no mention was made of the total number of patients with documented gout concurrently seen by the same investigators. Thus, some uncertainty remains regarding the prevalence of initially negative joint aspirates in a population of patients with crystal-proved gout.

In the patients described, urate crystals were found on aspiration of a different joint a few hours later (Cases 1 and 4) and three months later (Case 5) or the same joint $12 \mathrm{hr}$ later (Case 3) and one month later (Case 2). Cases 1, 2, 4 and 5 were seen at the Veterans Administration Hospital where during the same 30-month period gout was documented on initial SF analysis in 103 patients. The ratio of $4: 107$, or $4 \%$, parallels the findings from the earlier reports. It must be pointed out, however, that some patients with gout and initially negative SF analysis may not have been subject to repeat joint aspiration owing to various reasons such as a good response to therapy or lack of follow-up. Thus, the observed ratio represents a minimal estimate of a phenomenon whose true frequency may be very difficult to assess.

Interestingly, the initially crystal-negative fluids did not differ in leucocyte count, percentage of PMNs and quality of the mucin clot from those initially crystal-positive, in which the median and range values were $11.7(0 \cdot 8-152) \times 10^{\circ} / 1,83(38-99) \%$ and fair (fair to poor) respectively.

It is unclear why the initial aspirate in the patients presented and in those previously reported by others failed to show crystals. Loculation, previous digestion of the crystals, an immunological basis for the inflammation, and observer error, have all been considered (Schumacher et al., 1975). Whatever the final explanation will be, it is important to realize that, despite its rarity, an initially negative SF analysis does not entirely eliminate gout as a diagnostic possibility.

\section{Addendum}

While this manuscript was in press, Honig et al. (1977) reported the electron microscopic finding of urate and calcium pyrophosphate crystals in synovial fluid after polarizing microscopy had failed to reveal crystals. Thus, in selected cases, electron microscopic examination of synovial fluid may be crucial for initial documentation of crystal-induced synovitis.

\section{References}

Cohen, A.S., Brandt, K.D. \& KReY, P.R. (1975) Synovial fluid. In: Laboratory Diagnostic Procedures in the Rheumatic Diseases, 2nd edn (Ed. by A. S. Cohen), pp. 1-62. Little, Brown and Company, Boston.

Honig, S., Gorevic, P., Hoffstein, S. \& Waissmann, G. (1977) Crystal deposition disease. Diagnosis by electron microscopy. American Journal of Medicine, 63, 161.

MCCARTY, D.J. \& Hollander, J.L. (1961) Identification of urate crystals in gouty synovial fluid. Annals of Internal Medicine, 54, 452.

MCCARTY, D.J., Jr (1965) The inflammatory reaction to microcrystalline sodium urate. Arthritis and Rheumatism, $8,726$.

Schumacher, H.R., Jimenez, S.A., Gibson, T., Pascual, E., Traycoff, R., Dorwart, B.B. \& Reginato, A.J. (1975) Acute gouty arthritis without urate crystals identified on initial examination of synovial fluid: Report of nine patients. Arthritis and Rheumatism, 18, 603.

Zvaifler, N.J. \& Pekin, T.J. (1963) Significance of urate crystals in synovial fluids. Archives of Internal Medicine, $111,99$. 